\title{
THE VARICOSE TRIBUTARIES OF THE SUPERFICIAL FEMORAL VEIN PASSING INTO HUNTER'S CANAL
}

By Harold Dodd, Ch.M., F.R.C.S.

Surgeon to Royal London Homoepathic Hospital; King George Hospital, Ilford; Royal Hospital, Richmond; St. Mary's Hospital Group, Paddington

In 1954 a woman was operated on for bilateral varicose long saphenous veins. The saphenofemoral junctions were tied and the saphenous trunks were stripped from the groin to the ankles. Six months later she returned with almost identical varices. How could they have filled? Reexamination showed that when the veins were emptied, and a tourniquet applied at the groin, on standing they immediately appeared, indicating a source of filling below the sapheno-femoral junction which, even if it had not been tied, was controlled by the tourniquet. The band was reapplied at the lower third of the thigh, i.e., at the distal end of Hunter's canal; on standing the veins remained empty, showing that the leaking point was above the tourniquet. At re-operation it proved to be at the centre of Hunter's canal. That a communicating vein entered the superficial femoral vein in Hunter's canal and could become incompetent was known from Turner Warwick's (I93I) and Dow's (195I) studies, but this was the first time the writer had found it to be varicose.

A further instructive experience was gained when a stripper introduced at the ankle into the internal saphenous vein did not appear in this vessel at the groin, but was ultimately found in the common femoral vein; it had entered the superficial femoral vein from the long saphenous vein by a varicose communicating vein passing through Hunter's canal (seen since on two occasions).

Evidence of the incompetence of the Hunter's canal perforating veins has been given by venograms (Fig. I). These have shown varicosities passing downwards from the lower end and others passing medially from the middle and upper part of the canal, thus suggesting that more than one vessel might be defective; the operation findings described later confirm the presence of several vessels.

These experiences indicated that when diagnosing varicose veins, tributaries of the superficial femoral vein passing into Hunter's canal must be considered. These vessels have been diagnosed and operated on 52 times, 12 being in untreated varicose legs (see Fig. 2), and 40 with persistent varices after operation on the long saphenous vein (Fig. 3). The left leg was affected 26 times and the right 24; it was bilateral in two. The sexes were equally affected.

\section{Anatomy of the Communicating Veins of Hunter's Canal (CV-H)}

The operations on the communicating veins of Hunter's canal have led to the definition of theie anatomy. From now over 50 exposures of the canal it has been found that there are three or fou? small arteries from the superficial femoral artery accompanied by venae comites which supply sartorius and the antero-medial superficial tissues of the thigh. They arise at approximately the upper, middle and lower points of Hunter's canal. The descending geniculate venae comites often join the superficial femoral vein at the adductor opening together with the lowest vessels (Fig. 4). A similar artery with venae comites may pass laterally from under the outer border of sartorius. In the last 16 operations there were three arteries with venae comites in $I 3$ patients, there were four in two patients, and there were five in one.

These venae comites are tributaries of the superficial femoral vein and the operations have shown that any of them may be varicose and enlarged to an impressive size. The following have been noted:-

In to persons, a single varicose communicating vein was found. In ro others, there were two varicose tributaries, and in one, three incompetent veins were present. Table $\mathrm{I}$.

The site of these varicose tributaries is interesting; the lowest vein, sometimes with the descending genicular vein, was affected on $\mathrm{I}_{5}$ occasoins; the middle in ro and the uppermost in three, so 

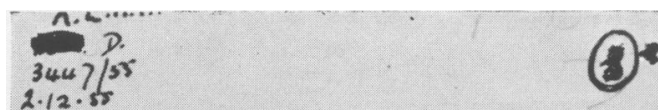

$2 \cdot 12.58$

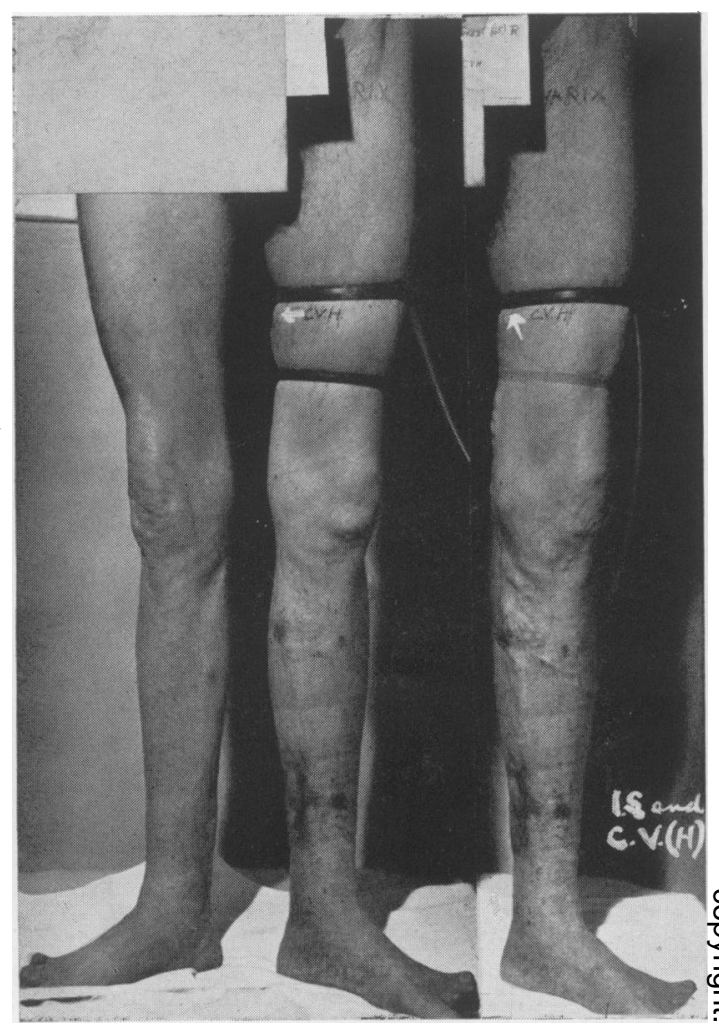

FIG. 2.-A case of varicose internal saphenous and communicating vein of Hunter's canal. The tourniquet test is shown.

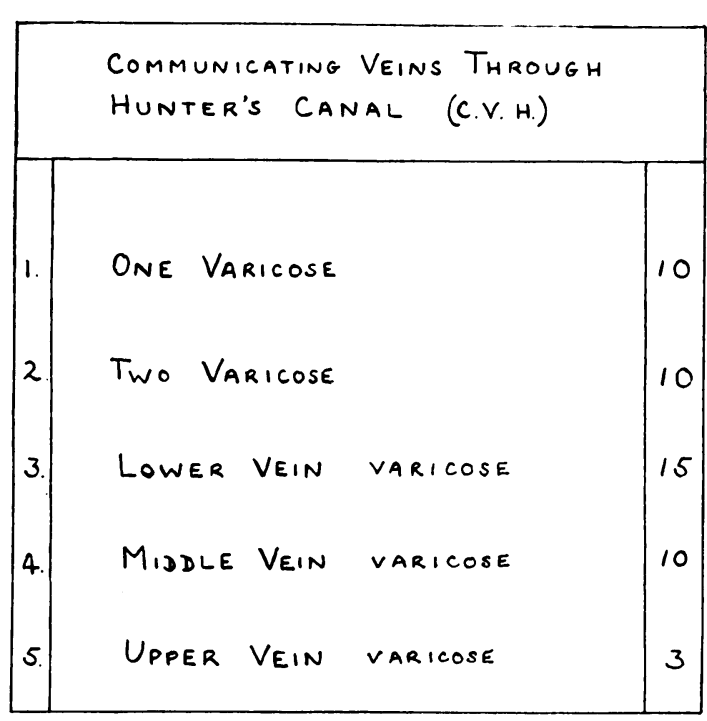

TABLE 1.-Details of the finding in 20 consecutive operations on Hunter's canal communicating veins.
FIG. 1.-Venogram showing an incompetent Hunter's canal vein. 


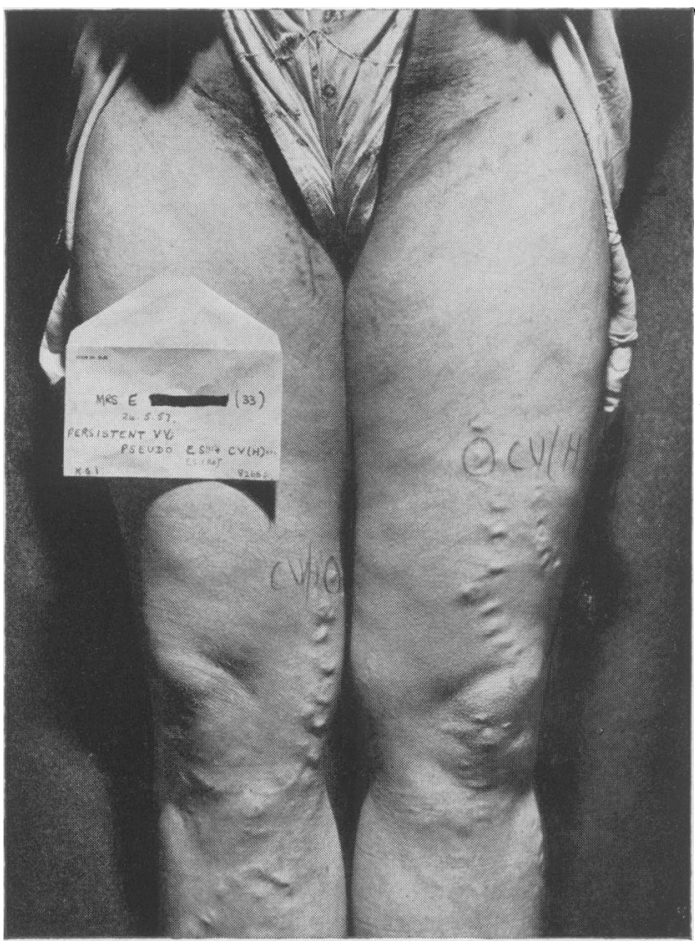

Fig. 3.-Bilateral varicose Hunter's canal communicating veins after sapheno-femoral ligation (see scar in groin), and stripping of the varicose long saphenous veins. that the lower end of Hunter's canal is the more important.

\section{Pathology}

Deep venous thrombisis of the lower limb may affect the posterior tibial venae comites, popliteal, femoral and iliac veins in continuity or in sections, as, for instance, only the posterior tibial or femoroiliac veins. Cockett's studies showed that the ankle perforating veins may be thrombosed by a retrograde spread from the soleal veins and posterior tibial venae comites, and that when they recanalize their valves are destroyed and the high pressures generated by the calf-muscle-pump pass into the superficial ankle veins and render them varicose. It seems feasible that by a process of retrograde propagation deep thrombosis from the superficial femoral vein into the perforating tributaries they may become incompetent on recanalization. Alternatively they may also be thrombosed and their valves destroyed by spread of phlebitis from superficial veins. Further, from the patients treated, the opinion has slowly formed that ulceration of the ankle seldom occurs from varicosity of the long saphenous vein alone, but from a combination with incompetent short saphenous, ankle perforators or varicose communicating veins passing into Hunter's canalo (Fig. 2). Of the patients treated in this study, 35 per cent. had ulceration and 50 per cent.0긍 eczema. Hogensgärd and Stürup also regard the

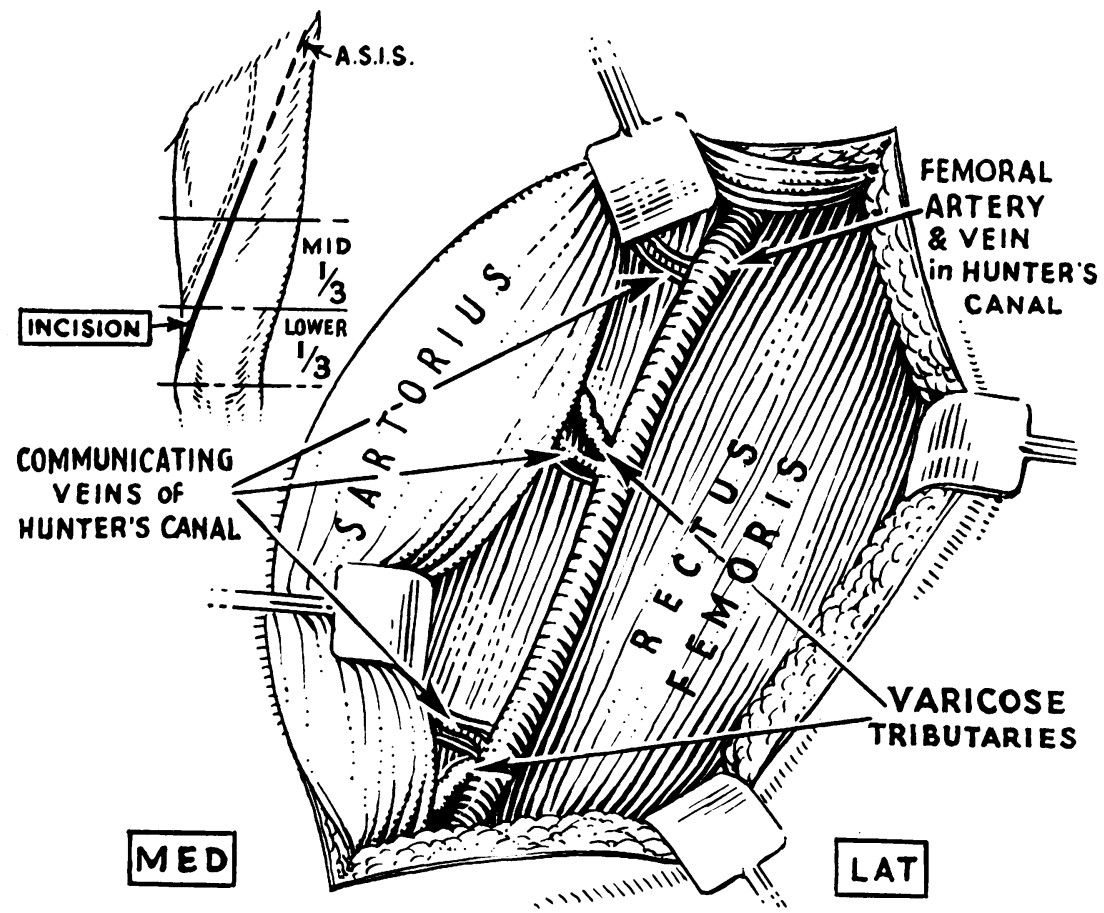

FIG. 4.-The landmark of Hunter's canal and line of incision. The average anatomy of the communicating veins of Hunter's canal. 


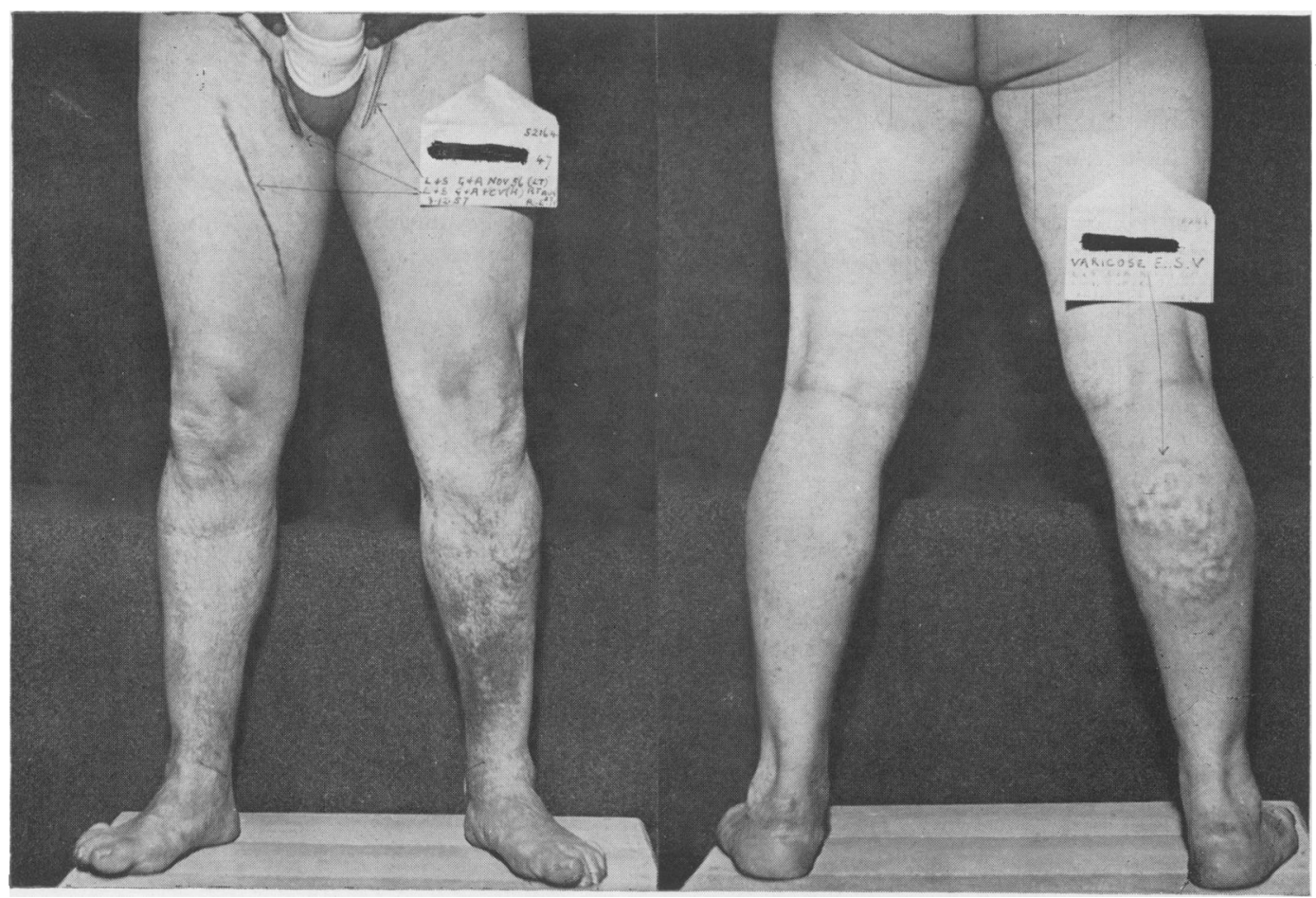

Fig. 5.-An overlooked varicose short saphenous vein after ligation of the long saphenous and communicating vein in Hunter's canal.

'Hunter communicators' as important in their causation.

\section{Symptoms, Signs and Diagnosis of Incompetent Tributaries of the Superficial Femoral Vein Passing Through Hunter's Canal (CV-H)}

Varicose veins in the lower thigh and leg can be filled by the varicose long saphenous vein but also by incompetent communicating veins going through Hunter's canal. Since becoming aware of the incompetence of these, they have been found incompetent in about 20 per cent. of patients with long saphenous varicosity. Therefore, the two must be differentiated.

On inspection, not infrequently there is a cluster of varices over Hunter's canal area (Fig. 3), or above the antero-medial aspect of the knee.

Incompetence of the long saphenous vein tends to obscure varicosity of an incompetent vein of Hunter's canal. This is partly because it is not considered, for varicosity of the long saphenous vein is so frequent that it is prone to be assumed in varices of the medial aspect of the thigh and leg. Further, both fill varicose veins from the midthigh to the ankle. Again, at the tourniquet examination, the band is often placed ' somewhere' on the thigh which will control the long saphenous vein, but not necessarily the Hunter's canal perforating veins. When such a band is released, the veins often fill and the long saphenous vein is deemed to be varicose. This error is avoided if, after emptying the veins, the tourniquet is placed at the groin; then, when the patient is standing, if a Hunter's canal vein is faulty, the varices will fill appreciably within 20 seconds; this distension is accelerated if the patient stands on the toes twicean action which squirts blood out through incompetent communicating veins. If the tourniquet is 'whipped' off as soon as the upright position is gained, there is not time for the varices to fill from a leaking Hunter's canal vein alone, and the varices are free to fill from any source. As varicosity of the long saphenous vein is common this is often deemed to be the leaking vessel.

The diagnosis of the varicose communicating veins of Hunter's canal $(\mathrm{CV}-\mathrm{H})$, is now apparent. After emptying the veins the tourniquet is placed at the groin; the person stands, rises to tip-toe twice, and the leg and thigh are watched for 20 seconds before removing the band. If the CV-H is faulty, the veins will fill steadily, and digital palpation of them will confirm that they contain blood under pressure. If the long saphenous vein 
is also incompetent then, on release of the groin constriction, the varices become still more prominent and tense. Usually a leak at the sapheno-femoral junction and of the communicating veins passing into Hunter's canal are associated, but the latter can be the only leak, both in primary or recurrent varices.

Again, if a tourniquet is placed at the groin and the lower third of the thigh, i.e., at the distal end of Hunter's canal, leakage from the CV-H and the long saphenous vein is controlled (Fig. 2). If any varices fill, they do so from the varicose tributaries of the popliteal vein (including the short saphenous vein), or from the ankle communicating veins. (The state of these will have been tested already by appropriate tourniquets.) If the short saphenous vein is varicose, then it must be excluded during the tests first by a band at the knee-joint. When the patient stands the occlusion is continued by substituting pressure of the thumb on the middle of the popliteal space while the upper tourniquets are released. On removal of the lower thigh band, leakage from the $\mathrm{CV}-\mathrm{H}$ will steadily fill the varices. (Filling from the long saphenous vein is still excluded by the groin tourniquet; Fig. 2.) Fig. 5 illustrates the need to be aware of the incompetence of the short saphenous vein.

\section{Percussion Test}

On percussing the varicose internal saphenous vein from the foramen ovale downwards, an impulse can be felt in the varices in the leg, but not if it is sound. If only the CV-H is faulty, as the level of percussion passes down the thigh and strikes over Hunter's canal, a faulty vein joining here causes an impulse to be felt in the varices below. This is a delicate and accurate sign.

Globular blow-outs. Arnoldi points out the frequency of these in the Hunter's canal area in association with incompetent $\mathrm{CV}-\mathrm{H}$.

\section{Venogram}

It is seldom that recourse to a venogram is necessary, but it will show the opaque medium passing from the superficial femoral vein by an incompetent perforating vein into the varices of the thigh (Fig. I). In efficient communicating veins, because of their valves, no dye can pass outwards.

\section{An Operative Diagnosis}

Occasionally at operation for incompetence of the long saphenous vein, this vessel is insignificant and doubtfully varicose, and would not account for the gross varices lower in the limb. The notes are re-read for the physical signs, and if there are enlarged veins in the lower half of the thigh, the tributaries of the superficial femoral vein passing into Hunter's canal should be explored. One such case has been done with reward.

\section{Treatment of the Incompetent Communicating Vein of Hunter's Canal}

In the earlier patients, the deep fascia in the area of the suspected faulty vein was searched for varicose communicating veins, occasionally unsuccessfully. Later the inner border of sartorius was defined as a guide to the vessels with more success, and now the principle followed is to expose Hunter's canal in its entirety in the middle third of the thigh as it lies under sartorius. All the superficial tributaries of the superficial femoral vein passing under either border of or through sartorius muscle are seen, and those which are varicose are divided flush on the femoral vein (Fig. 4).

Three contingencies may arise clinically:-

(I) The incompetent CV-H may be the only leak of high pressure from the deep to the superficial veins, possibly a varicose long saphenous vein has already been efficiently treated (Fig. 3 ).

(2) The long saphenous vein may also be varicose (Fig. 2), or may have been operated on inadequately before.

(3) Other leaking veins may also be presento such as the short saphenous or ankle communicat ing veins.

\section{The Incision}

The incision is rather more than the middle third of the line joining the anterior superior iliac spine to the adductor tubercle of the femur. The skin, fat and deep fascia are divided to expose the outer border of sartorius which muscle is widely mobilized, and elevated until its inner border is clearly seen and the superficial femoral vessels are visible bulging through the aponeurotic roof of Hunter's canal (Fig. 4).

Generally, three small arteries, accompanied by venae comites, pass medially from the superficial femoral artery (Fig. 4). One or two of these venae comites may be grossly enlarged and obviously varicose. They are divided at their endings. Occasionally a large vein passes through the substance of sartorius and, if it is varicose, this, too, is ligated.

The wound is retracted maximally at its lower end so that the superficial femoral vessels passing through the adductor opening can be seen; a large varicose medial geniculate venae comites may be found here.

Varicosity of the Internal Saphenous Vein and the Communicating Vein of Hunter's Canal

The long saphenous vein is ligated flush on the 
femoral vein. A stripper is passed along it from the ankle.

In recurrent long saphenous vein incompetence, exposure of the sapheno-femoral junction is difficult, due to scar tissue, and the mass of veins which follow an incomplete procedure. These can be avoided if the femoral sheath is opened at Poupart's ligament and the femoral vein traced down to the sapheno-femoral union, where the long saphenous vein is terminally secured beneath the cicatrix of the previous procedure.

Hunter's canal is opened through a separate incision, and the varicose communicating veins are divided as described.

\section{Other Incompetent Veins}

These may be ankle communicating veins, or the short saphenous vein with other varicose tributaries of the popliteal vein. The ankle veins are divided immediately after the Hunter's canal veins, but the short saphenous vein is done two to three days later. The writer is reluctant to undertake two major vein procedures at one operation session because of the danger of thrombosis and a breach in asepsis.

\section{Conclusion}

Varicose communicating veins passing into the superficial femoral vein through Hunter's canal are described. They are often missed in diagnosing varicose veins, and are a cause of persistent varices after operation. They contribute to eczema and ulceration at the ankle. The diagnosis and treatment are detailed.

\section{REFERENCES}

I. COCKETT, F. B. (I953), 'Pathology and treatment of venous ulcers of the leg.' M.S. Thesis. London.

2. DOW, J. D. (1951), Brit. F. Radiol., 24, I82; f. Fac. Radiol. (Lond.), ii, 180.

3. TURNER WARWICK. W. (r93I), 'The rational treatment of varicose veins and varicocoele,' p. 88. London. Faber and Faber.

4. HOGENSGARD, I. C., and STURUP, H., Acta Chir. Scandinav (1950), 99, $5 \mathrm{r} 8$.

An Address Book for the Medical profession, showing how to reach the various Colleges, Societies, Institutes and Hospitals in or near London

New (Fourth) Edition: 1954

Price 2s. 6d. (3s. Od., post free)

Published by the

FELLOWSHIP OF POSTGRADUATE MEDICINE

60 Portland Place, London, W.I

Bibliography continued from page $2 \mathrm{I}-$ P. B. B. Gatenby, M.D., M.R.C.P.(Lond.), F.R.C.P.I. BIBLIOGRAPHY

BENSTEAD, N., and THEOBALD, G. W. (1952), Brit. med. F., i, 407.

COLEMAN, D. H., STEVENS, A. R., and FINCH, C. A. (I955), Blood, 10, 567 .

EDGAR, W., and RICE, H. M. (1956), Lancet, i, 599.

FISHER, M., and BIGGS, R. (1955), Lancet, i, 385 .

FRANKLIN, M., ROHSE, W. G., de la HUERGA, J., and KEMP, C. R. (1958), F. Amer. med. Ass., 166, 1685 .

FULLERTON, H. W. (1934), Edinb. med. F., 4i, 99.

GATENBY, P. B. B., and LILLIE, E. W. (1955), Lancet, i, 740.

GILES, C. (1958), Personal Communication.

GILLHESPY, R. O. (1955), Med. Illus., 9, 147.

GIRDWOOD, R. H. (1952), Brit. med. f., i, 599.

GOETSCH, A. T., MOORE, C. V., and MINNICH, V. (1946), Blood, i, 129.

HALER, D. (1952), Brit. med. F., il, 1241.

HEATH, C. W. (1933), Arch. intern. Med., 51, 459.

JENNISON, R. F., and ELLIS, H. R. (1954), Lancet, ii, 1245 .

KERR, D. N. S., and DAVIDSON, S. (1958), Ibid., ii, 483, 489. O'SULLIVAN, D. J., HIGGINS, P. G., and WILKINSON, J. F. (1955), Lancet, ii, 482 .

REZNIKOFF, P., and GOEBEL, W. F. (1937), f. clin. Invest. 16, 547 .

SCOTT, J. M. (1956), Brit. med. F., ii, 635.

SCOTT, J. M., and GOVAN, A. D. T. (1954), Brit. med. F., ii, 1257. SEEBERG, V. P., HIDALGO, J., and WILKEN, W. (1954), Science, 119," 608 .

WILL, J. J., and VILTER, R. R. (1954), F. Lab. clin. Med., 44, 499. WITTS, L. J. (1931), Proc. roy. Soc. Med., 24, 543.

WITTS, L. J. (1933), Proc. roy. Soc. Med., 26, 607.

WITTS, L. J. (1936), Lancet, $i$, I, 